\title{
IRRIGATION WATER MANAGEMENT TECHNIQUES FOR LOWLAND FURROW- IRRIGATED SOYBEAN IN SOUTHERN BRAZIL
}

\author{
Elisa A. Gollo ${ }^{1 *}$, Adroaldo D. Robaina ${ }^{1}$, Marcia X. Peiter ${ }^{1}$, \\ Rafael Z. Goulart ${ }^{2}$, Miguel Chaiben Neto ${ }^{1}$
}

${ }^{1 *}$ Corresponding author. Universidade Federal de Santa Maria/ Santa Maria - RS, Brazil. Email: elisagollo@hotmail.com | ORCID ID: https://orcid.org/0000-0003-2610-2198

\section{KEYWORDS}

surface irrigation, crop irrigation in raised seedbeds, design and evaluation of irrigation systems, soybean yield potential.

\begin{abstract}
Different water management strategies should be investigated to ensure adequate water supply to furrow-irrigated soybean plants in lowlands. This study examined the performance and efficiency of furrow irrigation techniques and related them to the soybean yield potential in lowland fields of Southern Brazil in the 2017/18 growing season. An experiment was conducted on raised seedbeds to evaluate furrow irrigation techniques: full irrigation with cutback, irrigation during the advance phase with low inflow, irrigation during the advance phase (cutoff), surge irrigation, and no irrigation. The design parameters, efficiency of the techniques, agronomic characteristics, and the grain yield of the soybean crop, were evaluated. The overall performance of the cutback technique in furrow irrigation was superior, followed by the surge irrigation, cutoff, and low inflow techniques. Furrow irrigation increased soybean yield in lowlands, and the cutback technique was the best to guarantee the soybean yield potential in lowlands, resulting in a $29 \%$ yield increase compared to non-irrigated.
\end{abstract}

\section{INTRODUCTION}

The soybean cultivation in lowland fields of Rio Grande do Sul (RS), Brazil, which was traditionally used for irrigated rice, is a recent growing phenomenon driven mainly by the need for diversification. The yield capacity of these areas declined owing to the monoculture of rice, which has caused troublesome weed infestation, among other factors (Sartori et al., 2016). Therefore, efficient weed control and better market conditions, as provided by crop rotation with soybean, highlight the importance of this practice for the technical and economic sustainability of lowlands (Marchesan, 2016; Bortoluzzi et al., 2017)

However, some adjustments should be made in these areas before the introduction of soybean, because the areas are inappropriate for this crop production in varying degrees (Vernetti Junior et al., 2009; Bueno et al., 2020). Factors such as geographical location, land position and slope, and soil physical characteristics of the lowlands of Rio Grande do Sul contribute to the occurrences of waterlogging and, paradoxically, water deficit, which are considered to be the main limiting factors for the expression of soybean yield potential in lowlands (Goulart et al., 2020).

The use of raised seedbed crop system to improve poor drainage in lowlands has been recently reported (Gollo et al., 2020; Cassol et al., 2020). Raised seedbeds also improves the physical characteristics of the soil and allows the use of a furrow irrigation system (Sartori et al., 2015; Giacomeli et al., 2016; Sartori et al., 2016).

Water supplementation for soybean crop in lowland fields is an important strategy. Rainfall variability in the southern half of Rio Grande do Sul (RS) and the low storage capacity of water in lowland soils, owing to successive soil preparations for irrigated rice, justify the use of an irrigation system (Zanon et al., 2016; Rocha et al., 2017). The water catchment and conduction structures used for rice irrigation in these areas favor the adoption of surface irrigation systems for soybean, as this minimize initial investments and facilitate the return of rotation with rice crops.

Currently, rainfed crops in raised seedbeds in lowland areas of Rio Grande do Sul are commonly irrigated at flow rates ranging from 0.25 to $1.5 \mathrm{~L} \mathrm{~s}^{-1}$, and

\footnotetext{
${ }^{1}$ Universidade Federal de Santa Maria/ Santa Maria - RS, Brazil

${ }^{2}$ Instituto Federal de Educação, Ciência e Tecnologia Farroupilha/ Alegrete - RS, Brazil
}

Area Editor: Fernando França da Cunha

Received in: 9-2-2020

Accepted in: $12-27-2020$ 
water is applied in the furrow only in the advance phase, that is, until it reaches its end, so as to inhibit soil water saturation in the initial section of the furrows and potential decline in productivity (Faraco et al., 2016; Parfitt, 2017). However, this technique presents a considerable unequal distribution of water, which can result in an insufficient depth of water to meet the demand of the root system of plants. Moreover, there seems to be no concern in evaluating furrow irrigation systems for rainfed crops in lowlands, and related information are yet to be found in literature.

Identifying water application techniques, with regard to the combination of flow rates and application time, is necessary for adequate supply of water to plants and a sustainable soybean farming in that it optimizes the use of resources. Therefore, the objective of this study was to assess the performance and efficiency of furrow irrigation techniques such as cutback, low inflow, cutoff, and surge irrigation and related them to the soybean yield potential in lowland fields of Southern Brazil.

\section{MATERIAL AND METHODS}

The present study was conducted in the 2017/18 growing season at the crop science research lowland station of the Instituto Federal Farroupilha - Alegrete Campus. The station is in the physiographic region of the Western Border of Rio Grande do Sul, Brazil, at an altitude of $90 \mathrm{~m}$ above sea level at the geographical coordinates $29^{\circ} 42^{\prime} 57^{\prime \prime} \mathrm{S}$ and $55^{\circ} 31^{\prime} 54^{\prime \prime} \mathrm{W}$. According to the Köppen classification system, the local climate is classified as Cfa, a subtropical humid climate without a dry season and with an annual mean rainfall of $1400 \mathrm{~mm}$ (Alvares et al., 2013).

The soil is classified in Brazil as Gleissolo Melânico típico (Santos et al., 2018), i.e., an Entisol, with the following physical properties, which were observed immediately after sowing in the $0.0-0.20 \mathrm{~m}$ soil layer: particle density of $2.55 \mathrm{Mg} \mathrm{m}^{-3}$, soil bulk density of 1.47 $\mathrm{Mg} \mathrm{m}^{-3}$, field capacity of $0.34 \mathrm{~m}^{3} \mathrm{~m}^{-3}$, permanent wilting point of $0.11 \mathrm{~m}^{3} \mathrm{~m}^{-3}$, and basic intake rate of $15 \mathrm{~mm} \mathrm{~h}^{-1}$. The distribution of the soil texture in the same layer was $276 \mathrm{~g} \mathrm{~kg}^{-1}$ sand, $643 \mathrm{~g} \mathrm{~kg}^{-1}$ silt, and $80 \mathrm{~g} \mathrm{~kg}^{-1}$ clay.

The experiment was conducted on raised seedbeds in a randomized block design containing five treatments and three replicates. The treatments consisted of furrow irrigation techniques: full irrigation with advance and wetting phases and $50 \%$ reduction of flow rate after the advance phase (cutback); irrigation only during the advance phase with a flow rate of $0.25 \mathrm{~L} \mathrm{~s}^{-1}$ (low inflow); irrigation only during the advance phase (cutoff); surge irrigation in enough cycles to complete the advance phase (surge irrigation); and no irrigation (control). The cutback technique used a flow rate of $1 \mathrm{~L} \mathrm{~s}^{-1}$ during the advance phase, which was reduced to $0.5 \mathrm{~L} \mathrm{~s}^{-1}$ in the wetting phase. The duration of the wetting phase was defined by the water application time necessary to replace the required water depth in the final section of the field, using the soil basic intake rate as a parameter, being approximately 1.5 hours. The cutoff and surge irrigation techniques required a flow rate of $1 \mathrm{~L} \mathrm{~s}^{-1}$, which was the maximum available in the system. The flow rate of $0.25 \mathrm{~L} \mathrm{~s}^{-1}$ was used in the low inflow technique to simulate common furrow irrigation conditions in lowland fields of Rio Grande do Sul. In the surge irrigation technique, three ten-minute water application cycles were performed with a ten-minute pause in between. The experimental units measured $50 \times 3 \mathrm{~m}$ each and had a furrow slope of $0.1 \%$.

The soybean variety BMX Ícone of maturity group 6.8 was sowed on December 7, 2017. The sowing density was 14 seeds per linear meter. Inoculation, fertilization, and crop treatment recommendations were followed to produce an expected grain yield of $6,000 \mathrm{~kg} \mathrm{ha}^{-1}$ (Salvadori et al., 2016).

The raised seedbeds and irrigation furrows were built concomitantly along with sowing, using a seedbedsowing machine with a moldboard system. The raised seedbeds had a mean height of $0.12 \mathrm{~m}$, a width of $1.0 \mathrm{~m}$ between tops, and accommodated two soybean rows positioned at the respective edges of each bed spaced $0.5 \mathrm{~m}$ apart.

Water was distributed in the plots using a $200 \mathrm{~mm}$ diameter plastic gated pipe. The volume of water used on each irrigated plot was directly quantified by controlling the irrigation time for the flow rate used in each treatment. The depth of water applied in each irrigation technique was obtained from the ratio between the volume of water used in each plot and the total area of the irrigated plot for the different techniques. The advance time was quantified in all irrigation treatments every $10 \mathrm{~m}$ along the length of the plots.

The irrigation criteria used as reference was the mean limit of volumetric water content of the soil $\left(\theta, \mathrm{m}^{3}\right.$ $\mathrm{m}^{-3}$ ) in the $0.0-0.2 \mathrm{~m}$ layer of $60 \%$ of the field capacity of the soil, that is, irrigations were performed when $\theta$ was close to $0.204 \mathrm{~m}^{3} \mathrm{~m}^{-3}$. The need for irrigation was determined by monitoring $\theta$ throughout the growing season using capacitance/frequency sensors coupled to a datalogger. The sensors were installed at depths of 0.10 and $0.20 \mathrm{~m}$ at the beginning, middle $(25 \mathrm{~m})$, and end $(50$ $\mathrm{m})$ of the plots.

Shoot dry matter, yield components, and grain yield were measured at different soybean growth stages throughout the growing season. These evaluations were conducted in three different locations along the experimental units (their initial, middle, and final sections).

For dry matter evaluations, five plants were collected in sequence in the second sowing row of the plots. After collection, the shoots of the plants were dried in a greenhouse with forced air circulation at a temperature of $65^{\circ} \mathrm{C}$ until it attained a constant weight, and then weighed on a precision scale.

The yield components, such as the number of pods per plant, the number of grains per pod, 100-grain weight, and grain yield, were evaluated at the end of the crop season. The components were evaluated in ten plants collected during the R8 stage (harvest) (Fehr \& Caviness, 1977) by counting and weighing them on a precision scale. 
The grain yield was obtained by harvesting four central rows in each plot having a length of $5 \mathrm{~m}$ and a total area of $10 \mathrm{~m}^{2}$. After harvest, the grains were cleaned to remove impurities, weighed, and then corrected to a grain moisture of $13 \%$.

Irrigation water use efficiency (IWUE) by plants was determined at the end of the crop season, and was calculated from the ratio between the soybean yield and the total volume of irrigation water used for each irrigation technique, based on a methodology similar to the one used by Wood et al. (2017).

The gross value of production for each irrigation technique and the non-irrigated treatment was obtained by multiplying the respective grain yield by the mean value of the available soybean price indicator ESALQ/BM\&FBOVESPA of the Center for Advanced Studies in Applied Economics (CEPEA) for the period from January to November 2020. Daily rainfall data were collected from the Automatic Weather Station of the National Institute of Meteorology (INMET), located in Alegrete, Rio Grande do Sul, Brazil, near the experimental field.

The data obtained were subjected to a homoscedasticity test. Analysis of variance was performed using the $\mathrm{F}$ test and the means were compared using the Tukey test at $5 \%$ error probability.

\section{RESULTS AND DISCUSSION}

The cumulative rainfall for the 2017/18 growing season was $717.2 \mathrm{~mm}$, and the volumetric water content in the soil $(\theta)$ was close to $60 \%$ of field capacity on five different occasions (Figure 1), which is the criterion stipulated for irrigation. The five irrigation events took place at the vegetative and reproductive soybean growth stages in the four furrow irrigation techniques under evaluation. 

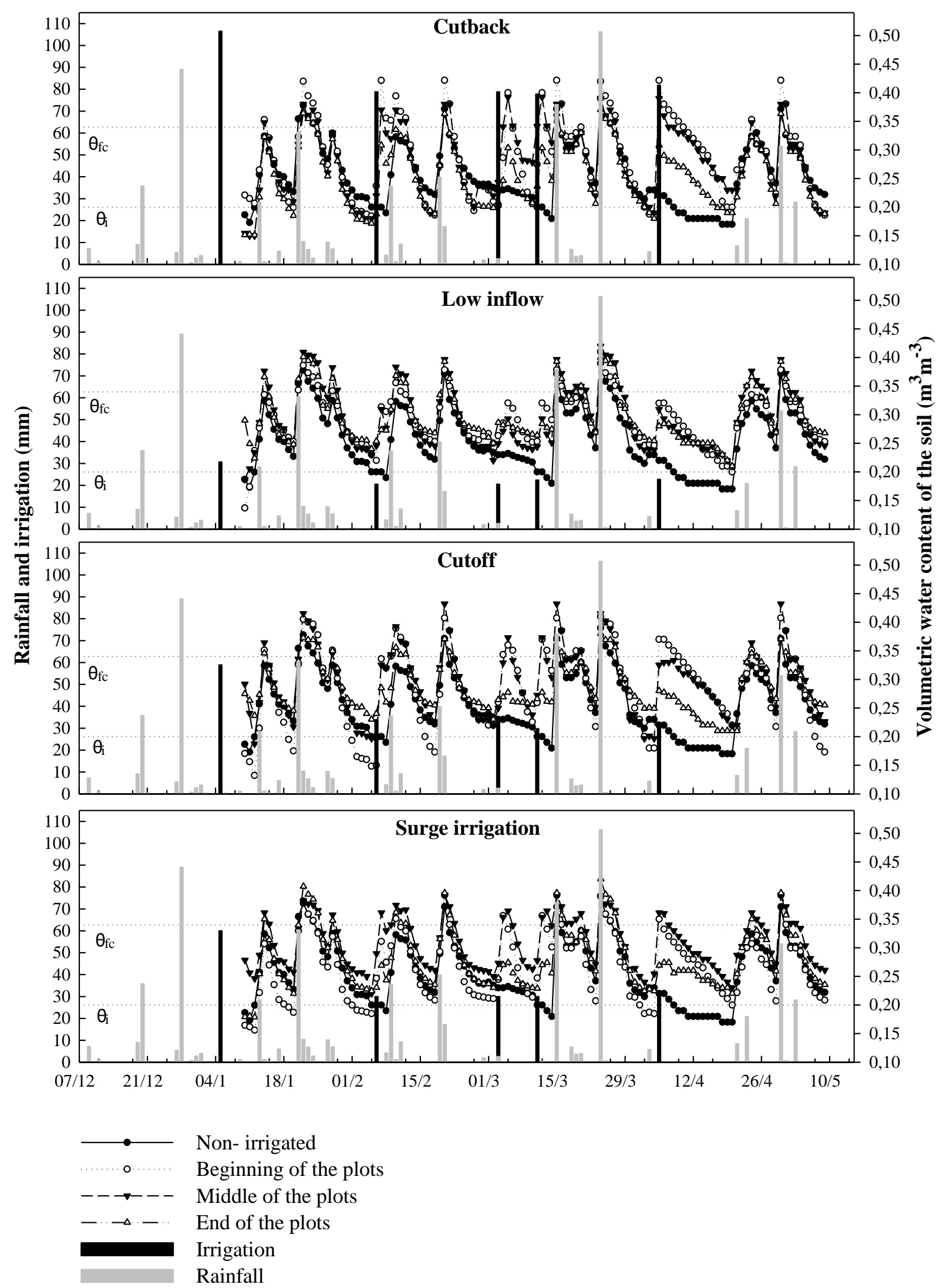

FIGURE 1. Volumetric water content of the soil at the beginning, middle, and end of the plots in the $0.0-0.20 \mathrm{~m}$ soil layer, rainfall, and irrigations performed in the furrow irrigation techniques: cutback, low inflow, cutoff, and surge irrigation; in lowlands in the 2017/18 growing season. Alegrete, Rio Grande do Sul, Brazil.

$\theta_{\mathrm{fc}}-$ Volumetric water content at the upper limit of water availability in the soil (field capacity); $\theta_{\mathrm{i}}$ - Volumetric water content at $60 \%$ of field capacity. 
The advance phase of the first irrigation was longer than that of the further irrigations in all techniques owing to variations caused by the reallocation of soil particles in the recently prepared furrows (Vanani et al.,
2017). In further irrigations, the advance phase stabilized owing to the consolidation of the soil infiltration characteristics in the furrows, which was observed in all techniques (Table 1).

TABLE 1. Advance time, irrigation water applied, water use, and irrigation water use efficiency (IWUE) of furrow-irrigated soybean crop in lowlands in the 2017/18 growing season. Alegrete, Rio Grande do Sul, Brazil.

\begin{tabular}{ccccccc}
\hline \multirow{2}{*}{\begin{tabular}{c} 
Furrow irrigation $\begin{array}{c}\text { Advance time } \\
\text { techniques }\end{array}$ \\
\cline { 2 - 7 }
\end{tabular}} & $\begin{array}{c}\text { First } \\
\text { irrigation }\end{array}$ & $\begin{array}{c}\text { Mean values of the } \\
\text { further irrigations }\end{array}$ & $\begin{array}{c}\text { First } \\
\text { irrigation }\end{array}$ & $\begin{array}{c}\text { Mean values of the } \\
\text { further irrigations }\end{array}$ & $\begin{array}{c}\text { Water } \\
\text { use }\end{array}$ & $\begin{array}{c}\text { Irrigation water use } \\
\text { efficiency }\end{array}$ \\
\cline { 2 - 7 } & & & 127.79 & $95.17 \mathrm{c}$ & 508.5 & $0.94 \mathrm{c}$ \\
Cutback & 61.0 & $33.50 \mathrm{~b}$ & 36.80 & $25.83 \mathrm{a}$ & 140.0 & $2.66 \mathrm{a}$ \\
Low inflow & 122.0 & $85.75 \mathrm{c}$ & 70.69 & $38.36 \mathrm{~b}$ & 224.0 & $1.81 \mathrm{~b}$ \\
Cutoff & 58.0 & $31.25 \mathrm{~b}$ & 72.00 & $36.00 \mathrm{~b}$ & 216.0 & $1.88 \mathrm{~b}$ \\
Surge irrigation & 60.0 & $26.00 \mathrm{a}$ & - & 3.48 & - & 3.90 \\
\hline $\mathrm{CV}^{(1)}(\%)$ & - & 6.06 & - & & & \\
\hline
\end{tabular}

*Means followed by lowercase letters in the column differ statistically based on the Tukey test at $5 \%$ error probability. ${ }^{(1)}$ Coefficient of variation determined by analysis of variance.

Advance time was similar in the cutback and cutoff techniques since they had the same management and $1 \mathrm{~L}$ $\mathrm{s}^{-1}$ flow rate during this phase. Even with the same flow rate, the advance phase was shorter in the surge irrigation technique owing to changes in the basic soil infiltration characteristics of the furrow during irrigation (Bishop et al., 1981). In this technique, the intermittent application of water to surface-irrigated furrows is performed in cycles of application and pause. During the first application cycle, the wetting front advances progressively down the furrow and the water infiltrates into the soil during the application and pause periods. In the subsequent application cycle, water applied advances rapidly across the wetted soil owing to a reduced infiltration rate caused by decreased matric potential of the soil, reducing the advance time (Bryant et al., 2017). According to El Sayed et al. (2019), this technique often has the shortest advance time. These authors also reported a greater water application uniformity in the surge irrigation technique, which was also observed in this study, where $\theta$ was higher in the middle section of the furrow compared to the cutoff technique (Figure 1).

The importance of the advance phase in furrow irrigation lies in the difference between the infiltration opportunity time at both furrow ends. According to the classic literature, the design and management of these irrigation systems aim to complete the advance phase in the shortest amount of time possible so as to minimize such differences (Walker \& Skorgeboe, 1987). To meet this objective, high non-erosion flows are recommended for the advance phase, with reductions in the cutback phase to minimize water losses by runoff at the end of the furrow (Bishop et al., 1981).

The unsatisfactory performance of the low inflow irrigation technique corroborates the aforementioned assumptions. The $0.25 \mathrm{~L} \mathrm{~s}^{-1}$ flow rate used in this technique was not enough to overcome the resistance offered by the soil characteristics at the $0.1 \%$ slope and maintain the water flow along the furrow. This resulted in a long and uneven advance time, with water accumulation at some points along the furrows. Moreover, the mean depth of $25.8 \mathrm{~mm}$ used in each irrigation was not enough to provide adequate water supply because was unable to raise $\theta$ to field capacity along the furrow length in the soil layer where the soybean roots grow (Figure 1). Based on these characteristics, the low inflow technique, commonly used in lowland fields, is not recommended for nonsystematized areas, in addition to its high costs in terms of time optimization and management.

The $\theta$ monitored in the raised seedbeds (Figure 1) was an important parameter to consider in performance evaluations. The cutoff and surge irrigation techniques showed a significant difference between the water depth replaced in the initial and middle sections and in the final section of the furrow, indicating that these techniques were not efficient in supplying adequate water depth for plant development. Although the cutback technique showed an increase in $\theta$ above field capacity in the initial and middle sections, only this technique provided adequate supply in the final section of the furrows, as the wetting phase supplied the water up to field capacity. The raised seedbeds were also efficient in draining the water excess, from both irrigation and rainfall, from the field throughout the crop season, corroborating the results of Gollo et al. (2020) and Fin et al. (2018). In addition to water supply characteristics of the irrigation techniques, the raised seedbeds were essential to ensure the correct growth and development of the soybean crop in lowlands.

Inherent to conventional furrow irrigation, the volume of water applied in the cutback technique was significantly higher compared to that used in the other techniques evaluated (Table 1). In the cutback technique, after the advance phase, a depth of water provided by the $0.5 \mathrm{~L} \mathrm{~s}-1$ flow rate was applied during the wetting phase during the time necessary to supply the water up to field capacity in the end of the furrows. Although the cutoff and surge irrigation techniques was different for advance times and distributions of $\theta$ along the furrow in the irrigations, they presented similar values of water use owing to the same flow rate and similar water application time used in both techniques.

Irrigation water use efficiency (IWUE) was higher in the low inflow technique, followed by the surge irrigation and cutoff techniques, which had similar results, 
and the cutback technique. Wood et al. (2017) and Bryant et al. (2017) also reported higher IWUE with the surge irrigation technique compared to conventional furrow irrigation, which was demonstrated by the cutback technique in this study.

Wood et al. (2017) stated that the main concept in adopt alternative irrigation techniques and/or strategies is to ensure an optimal $\theta$ so as to increase irrigation efficiency and crop yield. Thus, it is necessary to investigate the relationship between irrigation parameters discussed and the agronomic characteristics of soybean throughout the growth season.

Shoot dry matter (DM) in the vegetative and reproductive growth stages of soybean, yield components, and grain yield (Table 2) were the parameters used to evaluate the relationship between the furrow irrigation techniques and the soybean yield potential in lowlands.

TABLE 2. Shoot dry matter (DM) of soybean at different crop growth stages; yield components: pods per plant, grains per pod, and 100-grain weight; grain yield, and gross production value (GPV) of furrow-irrigated and non-irrigated soybean crop in lowlands in the 2017/18 growing season. Alegrete, Rio Grande do Sul, Brazil.

\begin{tabular}{|c|c|c|c|c|c|c|c|c|}
\hline \multirow{3}{*}{$\begin{array}{l}\text { Furrow irrigation } \\
\text { techniques }\end{array}$} & \multirow{2}{*}{\multicolumn{3}{|c|}{$\begin{array}{l}\text { Shoot dry matter } \\
\qquad\left(\mathrm{g} \mathrm{pl}^{-1}\right)\end{array}$}} & \multicolumn{3}{|c|}{ Yield components } & \multirow{3}{*}{$\begin{array}{c}\text { Grain } \\
\text { yield } \\
\left(\mathrm{kg} \mathrm{ha}^{-1}\right)\end{array}$} & \multirow{3}{*}{$\begin{array}{c}\text { Gross } \\
\text { production value } \\
\text { (US\$) }\end{array}$} \\
\hline & & & & \multirow{2}{*}{$\begin{array}{c}\text { Pods per } \\
\text { plant } \\
\left(\mathrm{n}^{\circ}\right)\end{array}$} & \multirow{2}{*}{$\begin{array}{c}\text { Grains per } \\
\text { pod } \\
\left(\mathrm{n}^{\circ}\right)\end{array}$} & \multirow{2}{*}{$\begin{array}{c}\text { 100-grain } \\
\text { weight } \\
(\mathrm{g})\end{array}$} & & \\
\hline & V7 & $\mathrm{R} 2$ & R5 & & & & & \\
\hline Non-irrigated & $6.30 \mathrm{~b}$ & $17.07 \mathrm{c}$ & $89.34 c$ & $43.26 \mathrm{~b}$ & $2.17^{\mathrm{ns}}$ & $18.23 \mathrm{~b}$ & $3361.3 \mathrm{~d}$ & 1278.41 \\
\hline Cutback & $6.75 a$ & $21.64 \mathrm{a}$ & $103.15 \mathrm{a}$ & $66.08 \mathrm{a}$ & 2.2 & $19.10 \mathrm{a}$ & $4773.9 \mathrm{a}$ & 1815.67 \\
\hline Low inflow & $6.87 \mathrm{a}$ & $17.63 b c$ & $93.62 b c$ & $50.03 \mathrm{ab}$ & 2.19 & $19.02 \mathrm{a}$ & $3729.0 \mathrm{c}$ & 1418.26 \\
\hline Cutoff & $6.82 \mathrm{a}$ & $19.86 a b$ & $98.49 \mathrm{ab}$ & $55.50 \mathrm{ab}$ & 2.22 & $19.06 \mathrm{a}$ & $4072.1 \mathrm{~b}$ & 1548.76 \\
\hline Surge irrigation & $7.00 \mathrm{a}$ & $20.30 \mathrm{a}$ & $97.67 \mathrm{ab}$ & $54.20 \mathrm{ab}$ & 2.22 & $19.13 \mathrm{a}$ & $4063.2 \mathrm{~b}$ & 1545.37 \\
\hline $\mathrm{CV}^{(1)}(\%)$ & 2.16 & 5.03 & 2.66 & 13.26 & 1.39 & 1.99 & 3.97 & - \\
\hline
\end{tabular}

* Means followed by lowercase letters in the column differ statistically based on the Tukey test at $5 \%$ error probability. ${ }^{\mathrm{ns}}$ Non-significant, in the columns. ${ }^{(1)}$ Coefficient of variation determined by analysis of variance.

The first irrigation performed in the V5 stage increased the shoot dry matter (DM) evaluated in V7, in all the techniques, which was also observed by Sartori et al. (2015) for the DM of soybean cultivated in lowland with surface irrigation during the vegetative stage. With the further irrigations, throughout the soybean development season, the differentiation between the techniques is evident. The best DM accumulation responses observed in the R2 and R5 stages were obtained for the cutback, surge irrigation, and cutoff techniques. The low inflow technique had a DM similar to that of non-irrigated treatment, demonstrating that this technique could not provide sufficient depth to supply the crop water demand, resulting in water deficit periods. Thus, there was a decline in leaf water potential, decreasing gas exchange and inhibiting main morphophysiological processes, and consequently resulting in poorly developed plants with reduced leaf area (Ferrari et al., 2015).

Soybean flowering and pod formation are the most sensitive phases to water deficit, but the effects of that also were observed when deficit occurs throughout the soybean growing season (Giménez et al., 2017). This can be confirmed by jointly analyzing the DM, yield components, and soybean yield for all the techniques (Table 2). The number of pods per plant was influenced by irrigation and was higher in the cutback technique, which provided the best water supply throughout the crop season. This yield component progressively declined in the other techniques and the non-irrigated treatment. The 100-grain weight was greater in the irrigation techniques than in the non-irrigated treatment, showing the importance of irrigation during the grain filling phase to maintain the adequate translocation of the plant reserves to the grain filling, resulting in greater weight. According to Gava et al. (2015), the occurrence of water deficit reduces the number of pods per plant and the 100-grain weight with directly damage to soybean grain yield.

Grain yield was higher in the cutback technique, followed by the cutoff and surge irrigation techniques, which showed similar results, and then the low inflow technique and the non-irrigated treatment. As reported, supplementary furrow irrigation was able to promote significant increase, of different magnitudes among the techniques, in plant agronomic characteristics and grain yield. Sartori et al. (2015) also recommended supplementary irrigation when $\theta$ is below $60 \%$ of field capacity in order to increase the soybean yield in lowlands.

The hypothesis previous to this work was that a higher $\theta$ in the initial furrow section caused by the furrow irrigation wetting phase would reduce the grain yield in lowland conditions. However, such an effect did not occur when the evaluated conditions were associated with the correct design of the system. The cutback technique guaranteed the soybean yield potential of soybean in lowlands owing to the adequate depth supply along the furrows. It was found that the raised seedbeds provided efficient drainage of the soil, promoting the outflow of excess and minimizing possible stress caused by waterlogging (Gollo et al., 2020). The maximum soybean yield $\left(4,773.9 \mathrm{~kg} \mathrm{ha}^{-1}\right)$ obtained with this technique was close to the maximum yield $\left(4,618 \mathrm{~kg} \mathrm{ha}^{-1}\right)$ obtained by Cassol et al. (2020) in raised seedbeds and furrowirrigated lowlands.

Although the cutoff and surge irrigation techniques differed in some irrigation parameters, they performed similarly for the variables related to the soybean yield potential in lowlands. These techniques did not ensure maximum soybean yield potential, but were adequate alternatives for increasing grain yield, with mean results $17 \%$ higher than that of the non-irrigation treatment. 
Even though the low inflow technique also increased grain yield compared to non-irrigated treatment, it had the worst results among the techniques evaluated. The low inflow present disadvantages when compared to the other techniques, being costly in relation to irrigation management characteristics and providing insufficient depth of water to supply crop demand.

Compared with the results obtained by Gubiani et al. (2018) $\left(3,565 \mathrm{~kg} \mathrm{ha}^{-1}\right.$ in the $2014 / 15$ growing season) and Fin et al. (2018) (over 4,000 kg ha ${ }^{-1}$ in the 2015/16 growing season), who also used raised seedbeds in lowlands, however, both seasons without water deficit due to regular rainfall distribution, the grain yield $(3,361.3 \mathrm{~kg}$ $\mathrm{ha}^{-1}$ ) obtained in this study with non-irrigated soybean indicates the risk of grain yield losses in years with irregular or insufficient rainfall, without an irrigation system. Rocha et al. (2017) attribute the highest risk of water stress in lowlands to the low water storage capacity of these soils.

Regarding to non-irrigated crop system, the maximum increase of grain yield with irrigation, represented by the cutback technique, was $1,412.6 \mathrm{~kg} / \mathrm{ha}$, equivalent to 23.5 bags of soybean per hectare. The average cost of furrow irrigation in lowland fields in Rio Grande do Sul that already have a water catchment and conduction system for irrigated rice, adapted from Silva et al. (2020) and updated price quote for grains from the CEPEA index for the period from January to November 2020 , is close to USD $41.07 \mathrm{ha}^{-1}$, which is equivalent to two bags of soybeans. On the basis that the other implementation and management costs are similar for both crop systems, discounting the average irrigation cost from the gross production value (GPV) (Table 2) obtained for the cutback technique, the maximum return associated with the use of irrigation in relation to rainfed system was US \$ 496.19. These results demonstrate the great potential of furrow irrigation for soybean in lowlands, which, in addition to ensuring safer weather conditions and increased production stability, has a reduced price and represents a significant economic return.

In general, the overall performance of the cutback technique was superior, followed by the surge irrigation, cutoff, and then low inflow techniques. Relating the performance of the techniques to the expression of yield potential of furrow-irrigated soybean in lowlands, it was observed that an isolated analysis of the water use and the irrigation water use efficiency did not accurately predict the performance of the techniques on crop characteristics, justifying the importance of their evaluation. As a suggestion, further studies on different growing conditions, soil types, slopes, furrow lengths, and the combination of more flow rates and irrigation times to obtain more comprehensive information on furrow irrigation techniques in lowlands are necessary.

\section{CONCLUSIONS}

Surge irrigation reduces the advance phase in furrow irrigation compared to traditional continuous application of water.

The low inflow technique in furrow irrigation is costly in terms of optimization of time, management, and soybean yield in lowlands.
The magnitude of the increase in the volumetric water content of the soil in the beginning of the field in the cutback technique has no negative impact on soybean yield. Moreover, the cutback technique has the best performance in ensure the expression of the soybean yeld potential, being recommended for lowlands.

Furrow irrigation increase soybean yield in lowlands. The use of irrigation minimizes the risk of losses during years with water deficit occurrence.

The irrigated crop system can increase the economic return of production by up to $28 \%$ compared with rainfed soybean in lowlands.

\section{ACKNOWLEDGMENTS}

The authors thank the Coordination for the Improvement of Higher Education Personnel (Capes) for granting a $\mathrm{PhD}$ scholarship to the first author.

\section{REFERENCES}

Alvares CA, Stape JL, Sentelhas PC, Gonçalves JLM, Sparovek G (2013) Köppen's climate classification map for Brazil. Meteorologische Zeitschrift 22: 711-728. DOI: https://doi.org/10.1127/0941-2948/2013/0507

Bishop AA, Walker WR, Allen NL, Poole GJ (1981) Furrow advance rates under surge flow systems. Journal of the Irrigation and Drainage Division, ASCE 107(IR3):257-264.

Bortoluzzi MP, Heldwein AB, Trentin R, Lucas DDP, Righi EZ, Leonardi M (2017) Risk of water surplus in soybean crop on haplic planosol soil in the Central Depression of Rio Grande do Sul State, Brazil. Ciência Rural 47(02):e20160170. DOI:

https://doi.org/10.1590/0103-8478cr20160170

Bryant CJ, Krutz LJ, Falconer L, Irby JT, Henry CG, Pringle III HC, Henry ME, Roach DP, Pickelmann DM, Atwill RL, Wood CW (2017) Irrigation water management practices that reduce water requirements for mid-south furrow-irrigated soybean. Crop, Forage \& Turfgrass Management 3. DOI: https://doi.org/10.2134/cftm2017.04.0025

Bueno MV, Campos ADS, Silva JT, Massey J, Timm LC, Faria LC, Roel A, Parfitt JMB (2020) Improving the Drainage and Irrigation Efficiency of Lowland Soils: Land-Forming Options for Southern Brazil. Journal of Irrigation and Drainage Engineering 146(8):04020019. DOI: https://doi.org/0.1061/(ASCE)IR.19434774.0001483 .

Cassol GV, Marchesan E, Massey JH, Robaina AD, Trivisiol VS, Werle I, Gollo E A, Giacomeli R, Schmatz R (2020) Raised seedbeds and irrigation increase the yield of soybean rotated with rice in lowland of Southern Brazil. Pesquisa Agropecuária Brasileira 55:e01398. DOI: https://doi.org/10.1590/S1678-3921.pab2020.v55.01398.

El-Sayed MM, Khalafalla MY, Gebreel M, AbdelMawgoud ASA (2019) Surge Flow Performance for Furrow Irrigation under Upper Egypt Conditions. Journal of Soil Sciences and Agricultural Engineering 10 (11):685691. DOI: https://doi.org/10.21608/jssae.2019.67356 
Faraco JR, Castro NMR, Louzada JÁ, Silva PRF, Schoenfeld R, Maass MB, Pagliarini N (2016) Rendimento de grãos e eficiência do uso de água da cultura do milho em áreas de cultivo de arroz inundado com diferente manejo de irrigação e drenagem. Irriga Edição Especial(Grandes Culturas). 1(1):274-290. DOI: https://doi.org/10.15809/irriga.2016v1n1p274-290

Fehr WR, Caviness CE (1977) Stages of soybean development. Ames: State University of Science and Technology, 11p.

Ferrari E, Paz A, Silva AC (2015) Déficit hídrico no metabolismo da soja em semeaduras antecipadas no Mato Grosso. Nativa 3:67-77. DOI:

https://doi.org/10.14583/2318-7670.v03n01a12

Fin SS, Marchesan E, Gubiani PI, Farenzena JAP, Murari MS, Coelho LL, Cargnelutti A, Aramburu BB (2018) Duration of the effects of scarification and raised bed associated with vegetation cover on soybean yield on an Alfisol. Pesquisa Agropecuária Brasileira 53:1230-1238. DOI: https://doi.org/10.1590/s0100-204x2018001100005

Gava R, Frizzone JA, Snyder RL, Jose JV, Fraga Junior EF, Perboni A (2015) Estresse hídrico em diferentes fases da cultura da soja. Revista Brasileira de Agricultura Irrigada 9(6):349-359. DOI:

https://doi.org/10.7127/rbai.v9n600368

Giacomeli R, Marchesan E, Sartori GMS, Donato G, Silva PRF, Kaiser DR (2016) Escarificação do solo e sulcadores em semeadora para cultivo de milho em Planossolos. Pesquisa Agropecuária Brasileira 51(3):261-270. DOI: https://doi.org/10.1590/S0100-204X2016000300008

Giménez L, Paredes P, Pereira LS (2017) Water use and yield of soybean under various irrigation regimes and severe water stress. Application of AquaCrop and SIMDualKc Models. Water 9(6):1-18. DOI: https://doi.org/10.3390/w9060393

Gollo EA, Robaina AD, Peiter MX, Marchesan E, Giacomeli R, Cassol, GV (2020) Implantation systems and surface irrigation for maize crop in lowland areas. Brazilian Journal of Maize and Sorghum 19:e1110. DOI: https://doi.org/10.18512/1980-6477/rbms.v19n1p10e1110

Goulart RZ, Reichert JM, Rodrigues MF (2020) Cropping poorly-drained lowland soils: Alternatives to rice monoculture, their challenges and management strategies. Agricultural Systems 177(102715):1-7. DOI: https://doi.org/10.1016/j.agsy.2019.102715

Gubiani PI, Müller EA, Somavilla A, Zwirtes AL, Mulazzani RP, Marchesan E (2018) Transpiration reduction factor and soybean yield in low land soil with ridge and chiseling. Revista Brasileira de Ciência do Solo 42:1-14. DOI: https://doi.org/10.1590/18069657rbcs20170282

Marchesan E (2016) Desenvolvimento de tecnologias para cultivo de soja em terras baixas. Revista Eletrônica Competências Digitais para Agricultura Familiar 02(01).

Parfitt JMB (2017) Irrigação e drenagem para cultivo de soja e milho. In: Emydgio BM, Rosa APSA, Oliveira ACB. Cultivo de soja e milho em terras baixas do Rio Grande do Sul. Embrapa, 341 p.
Rocha TSM, Streck NA, Zanon AJ, Marcolin E, Petry MT, Tagliapietra EL, Barlest D, Bexaira K P (2017) Performance of soybean in hydromorphic and nonhydromorphic soil under irrigated or rainfed conditions. Pesquisa agropecuária brasileira 52(5):293-302. DOI: https://doi.org/10.1590/s0100-204x2017000500002

Salvadori, JR, Bacaltchuk B, Deuner CC, Lamas GLCJ, Rizzardi MA, Lângaro NC, Ecosteguy PAV, Boller W (2016) Indicações técnicas para a cultura da soja no Rio Grande do Sul e Santa Catarina, safras 2016/2017 e 2017/2018. Passo Fundo, Editora Universidade de Passo Fundo, 127p.

Santos HG, Jacomine PKT, Anjos LHC, Oliveira VA, Lumbreras JF, Coelho MR, Almeida JA, Araujo Filho JC, Oliveira JB, Cunha TJ (2018) Sistema brasileiro de classificação de solos, Brasília, Embrapa, 5 ed. 356p. DOI: https://doi.org/ISBN 978-85-7035-198-2

Sartori GMS, Marchesan E, De David R, Carlesso R, Petry MT, Donato G, Cargnelutti A, Silva MF (2015)

Rendimento de grãos de soja em função de sistemas de plantio e irrigação por superfície em Planossolos. Pesquisa Agropecuária Brasileira 50(12):1139-1149. DOI: https://doi.org/10.1590/S0100-204X2015001200003

Sartori, GMS, Marchesan E, De David R, Carlesso R, Petry MT, Aires NP, Giacomeli R, Aramburu BB, Silva AL (2016) Soybean Tillage Systems and Physical Changes in Surface Layers of Two Albaqualf Soils. Revista Brasileira de Ciência do Solo 40(e0160019):1-15. DOI: https://doi.org/10.1590/18069657rbcs20160019

Silva PRF, Anghinoni I, Grohs M, Marchesan E (2020) Milho no contexto da lavoura arrozeira: manejo dos fatores relacionados à planta e viabilidade financeira.

Cachoeirinha, Instituto Rio Grandense do Arroz, 8p.

Vanani HR, Shayannejad M, Soltani Tudeshki AR, Ostad-Ali-Askari K, Eslamian S, Mohri-Esfahani E, Haeri-Hamedani, M, Jabbari H (2017) Development of a new method for determination of infiltration coefficients in furrow irrigation with natural non-uniformity of slope. Sustainable Water Resources Management 3:163-169. DOI: https://doi.org/10.1007/s40899-017-0091-X

Vernetti Junior FJ, Gomes AS, Schuch LOB (2009) Sucessão de culturas em solos de várzea implantadas nos sistemas plantio direto e convencional. Revista Brasileira Agrociência 15(4):37-42. DOI:

http://dx.doi.org/10.18539/cast.v15i1-4.1984

Walker WR, Skogerboe GV (1987) Surface irrigation: theory and practice. Prentice-Hall, New Jersey, Englewood Cliffs, 386p.

Wood CW, Krutz LJ, Falconer L, Pringle III HC, Henry B, Irby T, Orlowski JM, Bryant CJ, Boykin DL, Atwill RL, Pickelmann DM (2017) Surge Irrigation Reduces Irrigation Requirements for Soybean on Smectitic ClayTextured Soils. Crop, Forage \& Turfgrass Management 3(1):1-6. DOI: https://doi.org/10.2134/cftm2017.04.0026

Zanon AJ, Streck NA, Grassini P (2016) Climate and Management Factors Infl uence Soybean Yield Potential in a Subtropical Environment. Agronomy Journal 108(4):1447-1454. DOI: https://doi.org/10.2134/agronj2015.0535 